Etnográfica

Revista do Centro em Rede de Investigação em

Antropologia

vol. $12(2) \mid 2008$

Vol. 12 (2)

\title{
European Christianities at the turn of the millennium: an introduction
}

\section{Ruy Llera Blanes and Ramon Sarró}

\section{(2) OpenEdition}

\section{Journals}

Electronic version

URL: https://journals.openedition.org/etnografica/1761

DOI: 10.4000/etnografica.1761

ISSN: 2182-2891

\section{Publisher}

Centro em Rede de Investigação em Antropologia

\section{Printed version}

Date of publication: 1 November 2008

Number of pages: $371-376$

ISSN: 0873-6561

\section{Electronic reference}

Ruy Llera Blanes and Ramon Sarró, "European Christianities at the turn of the millennium: an introduction", Etnográfica [Online], vol. 12 (2) | 2008, Online since 03 July 2012, connection on 11 February 2022. URL: http://journals.openedition.org/etnografica/1761 ; DOI: https://doi.org/10.4000/ etnografica. 1761

Etnográfica is licensed under a Creative Commons Attribution-NonCommercial 4.0 International License. 


\section{European Christianities at the turn of the millennium: an introduction}

\section{Ruy Llera Blanes and Ramon Sarró}

Instituto de Ciências Sociais (UL)

DESPITE THE RECENT THESES ON THE “SOUTHERNISATION” OF GLOBAL Christianity (Jenkins 2002), the secularisation of our age (Taylor 2007) or the media fears towards "political Islam", Christianity is still a major definer or European identity in both historical and demographical terms. The recent discussions on the Europe's "Christian heritage" (regarding the content of the common treaty text) are but one example of the public and political recognition of this fact.

As Paul Gifford suggested, it seems that, despite the overwhelming fashion of secularist discourses in the last decades of the twentieth century, at the turn of the millennium, as if in sudden remembrance of the symbolic occasion (the celebration of Jesus' birth) - or perhaps inspired by its "apocalyptic" suggestion (Comaroff and Comaroff 2001), - "Christendom" returned to the agendas of social theory and public opinion (Gifford 2003). The currency of the concept of "secularisation" seems to have added to those of "fundamentalism" (in particular through its political agency - see e.g. Harding 2001; Gifford 2008), "conservatism" or even "prosperity" (for instance, regarding Neopentecostalism).

But after all, every year thousands still flock to St. Peter Piazza in the Vatican to attend the Papal Mass (while many millions are watching the broadcast), and pilgrimage sites such as Fátima or Santiago de Compostela are experiencing renewed attendance, amidst the growth of so-called "religious tourism". Thus, it is not a question of a "re-birth" of Christianity into novel forms, but rather a redefinition of its plural character, where new dynamics combine/ react/oppose to more traditional expressions that are nevertheless still active. 
Therefore, it is also true that the "Christian tradition" faces, today, many challenges. On the one hand, the secularist theses, however ideological (or even "prophetical", interestingly enough) they may seem to us now, did have a sociological background (see Berger et al. 1999). Namely, the decrease in traditional forms of church practice and allegiance in Europe - one of the key points behind Philip Jenkins' argument regarding the "southernisation" of Christianity. For Jenkins (and others), demographically speaking, given the decline of Christian allegiance in the "West", the "centre of gravity" of Christianity should no longer be looked for in Europe but in places like Africa or even Brazil (2002; 2007; see also Bediako 2000).

But, as Danièle Hervieu-Léger has pointed out, this has not necessarily implied the disappearance of the Christian tradition, but mainly its reconfiguration into "modern" religious practices (2005 [1999]). Hervieu-Léger's framework was similar to that of Grace Davie on her work on religion in "modern Europe": to confront the idea of a common European religious heritage or tradition (i.e., "Christianity") with the refraction of its expressions in the various European nations (Davie 2000).

In this line of thought, one of the main epistemological tenets of contemporary Christianity in Europe is, in fact, the concept of "pluralism" and/or "pluralisation". Despite the straightforward conceptual association between religious change/renewal and the idea of pluralisation, it would be incorrect to establish a cause-effect connection between both. Especially because, despite traditional historical approaches to religion and nation-states ("single-faith approaches" - see Kumar 2007), it is frequently acknowledged that the religious practices in Europe have, in most cases, been plural and should rather have been posed in terms of religious hegemony vs. minority. Such was the case, for example, for Portugal (see Dix 2008).

Perhaps this is why a good body of literature regarding "religion and globalisation" has flourished recently, defying the traditional epistemological circumscriptions that attempted to associate creeds to political entities - for instance, Catholic Spain, Orthodox Greece, Protestant Sweden, and so on (see e.g. Levitt 2007). If Christianity has always been characterised by an inherent trend towards universalism (Martin 2007), set forth by the Jesus in the gospel of Matthew (28, verse 19: "Go therefore and make disciples of all nations, baptising them in the name of the Father and of the Son and of the Holy Spirit"), today we observe how (1) contemporary mobility and migration have overcome traditional frontiers, and (2) proselytism and mission no longer see Europe as the place of origin, but often as a place of arrival.

Yet, what interests us most in this proposal, more than the discussion on the historical architecture behind the concepts of "heritage", "identity" and "pluralism", are the empirical contexts and expressions that arise, in 
post-millennium Europe, from these theoretical/ideological debates: the processes of mutual recognition in contexts of religious pluralism and interaction and, in consequence, the competition for the property of "real" Christianity. This is what happens, for example, when we approach the input of extraEuropean Christian migrants in the European scenery. When we observe the surge of, say, Brazilian Charismatic Catholics in Fátima, Neopentecostals in Western Europe (Aubrée 2003), Angolan/Congolese prophetic movements in Lisbon (see Sarró and Blanes 2008), Ghanaian Pentecostals in the Netherlands (see van Dijk 2004; ter Haar 1998), South Asian Christians in Europe (Jacobsen and Rak 2008), and so on, it is not surprising to find discourses and movements of reactions to the "unexpectedness".

Furthermore, the urgency of this venture becomes evident when even the concept of "Europe" is, today, submitted to debate (see, e.g., Amselle 2006; Gingrich 2006), and the idea of Christianity as a European construct is no longer taken for granted (see Sanneh 2003). Thus, an assessment of the role played by Christianity in the construction of "European religious identities" in the new millennium is, we believe, imperative - as is the in-depth ethnographic research on the persistence of this old religious heritage in the continent and the challenges it faces, thanks to new forms of understanding Christianity (Charismatic, Prophetic, Neopentecostal, etc.) coming from "the other side" of its frontiers (Africa, America, etc.).

\section{ETHNOGRAPHIC APPROACHES TO CONTEMPORARY CHRISTIANITY}

Despite the recognition of a novel, plural and revived Christianity in the European scenario, the ethnographic initiatives only just starting to cover these new realities; a few (indeed worthy) exceptions come to mind: as an anticipation, the edited volume on faits réligieux in Europe by Nicole Belmont and Françoise Lautman, that extensively mapped cases of traditional, changing and new expressions in end-of-century Europe (1993); the pioneering work of Dutch anthropologists regarding the surge of African Christian churches in that country (ter Haar 1998; 2003; van Dijk 2004), as well as of African scholars elsewhere (Adogame 2005; Asamoah-Gyadu 2006); the updated approach to pilgrimage sites such as Medjugorje in Bosnia (Claverie 2003) or Saintes-Maries-de-la-Mer in France (Bordigoni 2002). Other examples could follow. These approaches not only implied an important empirical update on the ongoing reconfigurations of Christianity in the European scenario of the new millennium, but also offered new ways of understanding contemporary Christianity. Such is the case, for instance, of Gerrie ter Haar, who, through her fieldwork with migrant African churches, reported the importance of "integration" as vector for understanding the actions and strategies of "foreign" churches in the Dutch territory (2003). 
Integration is, in fact, one of the key conceptual instruments for understanding many new or renewed Christian practices in the European territory; yet, many others, who are not directly mediated by processes of migration - for instance, conservative Evangelicalism in Sweden (Coleman 2000), Gypsy Pentecostalism in Southwestern Europe (Blanes 2008), new age pilgrimages that reinterpret the history of Christianity in France (Fedele 2008), eastern Christianity in postsocialist contexts (Naumescu 2008), etc. - may need other categories. Thus, the need of a continuous empirical update is evident.

This dossier proposes diverse discussions of contemporary Christianity in the European territory with a double objective: firstly, the documentation, through ethnographic methods, of diverse situations of the "lived-through" European Christianities. Secondly, the dialogue between new trends in the anthropology of religion and Europe as a "field". Not only do new theories inform the case studies here presented, but they also show that new theoretical proposals may emerge out of analysis what is happening in churches situated, so to speak, in our own neighbourhood.

Philippe Gonzalez, in one challenging paper in which Weber's individual beruf meets Durkheim's conscience collective in an unusual felicitous way, incorporates into a particular European context (Switzerland) the categories of ongoing debates regarding Pentecostalism in the North American academia: political allegiance and civic participation. Analysing the rhetoric of pastors and of participants in evangelical meetings in Switzerland, Gonzalez unearths the trend from a personal, spiritual regeneration to one in which it is the whole community which is reinvigorated through the Christian worship and in which the individual feels empowered not only as a believer, but as a citizen too.

Using a sociologically-informed ethnography, Maria M. Griera describes the disjunctions created within the Protestant sphere in Catalonia, showing how novel forms of Christianity, particularly those coming from Africa, must struggle for recognition against prejudices and somewhat racist understandings: how is it possible that people with these customs can call themselves Christian?

In sharp contrast with this sociological analysis, Carles Salazar takes us into the very heart of the Catholic devotion of a small Irish community by focussing on prayer - an all-too-often neglected area of ethnographic analysis, despite Marcel Mauss's influential work on it (Mauss 1909). Not only does Salazar show how important prayer is for his Irish interlocutors, but in doing so he opens new venues of research on the relationship between religious intent and exteriorization, establishing a dialogue between social and cognitive approaches to religious experience that, while not being rare in anthropology, it hardly ever feeds into debates of European forms of religiosity.

Finally, Deborah Puccio-Den approaches a seemingly non-religious domain: that of the Sicilian Mafia and its place in local political imagination. For Puccio-Den, Catholic religion works like a template against which the evil of 
the Mafia (and the very idea of Mafia as being "one" single body of evil) is understood, both in spontaneous manifestations (such as the conversion of a judge's house into a pilgrimage site) and through the conscious manipulation and association of images by politicians and by the church leaders (including the Pope himself), which eventually led to the identification of judges to martyrs and sacrificial victims, and to the blurring of boundaries between the legal and the religious ethos in this Christian society.

These case-studies are a sample of the diverse Christian practices observed in the European territory and of the multiple possible approaches for their understanding. Yet, all of them describe, in one way or another, the pervasiveness of religious ideas, productions and practices in social life - from political agency to criminal settings, bodily postures in domestic settings and theological discourses.

\section{REFERENCES}

ADOGAME, Afe, 2005, "African Christian communities in diaspora", in Ogbu Kalu (ed.), African Christianity: An African Story. Pretoria, University of Pretoria, pp. 494-514.

AMSELLE, Jean-Loup, 2006, "The world inside out. What is at stake in deconstructing the West?”, Social Anthropology, 14 (2), pp. 183-194.

ASAMOAH-GYADU, J. Kwabena, 2006, "African initiated christianity in Eastern Europe: Church of the 'Embassy of God' in Ukraine”, International Bulletin of Missionary Research, 30 (2), pp. 73-76.

AUBRÉE, Marion, 2003, “Un néo-pentecôtisme Brésilien parmi les populations immigrées en Europe de l'Ouest”, Anthropologie et Sociétés, 27 (1), pp. 65-84.

BEDIAKO, Kwame, 2000, "Africa and Christianity on the threshold of the third millenium:

The religious dimension", African Affairs, 99, pp. 303-323.

BELMONT, Nicole, and Françoise LAUTMAN, 1993, Ethnologie des Faits Réligieux en Europe.

Paris, Éditions du Comité des Travaux Historiques et Scientifiques.

BERGER, Peter, et al., 1999, The Desecularisation of the World: Resurgent Religion and World Politics. Grand Rapids, MI, Eerdmans.

BLANES, Ruy Llera, 2008, Os Aleluias. Ciganos e Evangelismo na Península Ibérica. Lisboa, Imprensa de Ciências Sociais.

BORDIGONI, Marc, 2002, "Le pèlerinage des Gitans, entre foi, tradition et tourisme", Ethnologie Française, 32 (3), pp. 489-501.

CLAVERIE, Elizabeth, 2003, Les Guerres de la Vierge. Une Anthropologie des Apparitions. Paris, Gallimard.

COLEMAN, Simon, 2000, The Globalisation of Charismatic Christianity. Spreading the Gospel of Prosperity. Cambridge, Cambridge University Press. 
COMAROFF, Jean, and John COMAROFF, 2001, "Aliens, Apocalypse and the postcolonial State”, Journal of Southern African Studies, 27 (3), pp. 627-651.

DAVIE, Grace, 2000, Religion in Modern Europe: A Memory Mutates. Oxford, Oxford University Press.

DIX, Steffen, 2008, "Roman Catholicism and religious pluralities in Portuguese (Iberian) History", Journal of Religion in Europe, 1 (1), pp. 60-84.

FEDELE, Anna, 2008, El Camino de María Magdalena. Un Recorrido Antropológico por la Ruta de Peregrinaje de la Nueva Espiritualidad. Barcelona, RBA.

GIFFORD, Paul (ed.), 2008, Evangelical Christianity and Democracy in Africa. Oxford, Oxford University Press.

GIFFORD, Paul, 2003, "2000 years and beyond: looking backwards and forwards", in Paul Gifford et al. 2000 Years and Beyond: Faith, Identity and the Common Era. London, Routledge.

GINGRICH, Andre, 2006, "Neo-nationalism and the reconstruction of Europe", Social Anthropology, 14 (2), pp. 195-217.

HARDING, Susan, 200 1, The Book of Jerry Falwell. Fundamentalist Language and Politics. Princeton, NJ, Princeton University Press.

HERVIEU-LÉGER, Danièle, 2005 [1999], O Peregrino e o Convertido. A Religião em Movimento. Lisbon, Gradiva.

JACOBSEN, Knut, and Selva RAK (eds.), 2008, South Asian Christian Diaspora: Invisible Diaspora in Europe and North America. Aldershot, Ashgate.

JENKINS, Philip, 2007, God's Continent: Christianity, Islam, and Europe's Religious Crisis. New York, Oxford University Press, USA.

—, 2002, The Next Christendom: The Coming of Global Christianity. Oxford, Oxford University Press.

KUMAR, Pratap, 2007, "Religious pluralism and religion education in South Africa", Method \& Theory in the Study of Religion, 18, pp. 273-293.

LEVITT, Peggy, 2007, God Needs No Passport. Immigrants and the Changing American Religious Landscape. London and New York, New Press.

MARTIN, David, 2007, "Master narratives and the future of Christianity", Zeitschrift für Religions und Geistesgeschichte, 59 (1), pp. 1-13.

MAUSS, Marcel, 1909, La Prière. Paris, Alcan.

NAUMESCU, Vlad, 2008, Modes of Religiosity in Eastern Christianity. Religious Processes and Social Change in Ukraine. Munster, Lit Verlag.

SANNEH, Lamin, 2003, Whose Religion is Christianity? The Gospel Beyond the West. Grand Rapids, MI, Eerdmans.

SARRÓ, Ramon, and Ruy Llera BLANES, 2008, “O Atlântico Cristão: apontamentos etnográficos sobre o encontro religioso em Lisboa”, in Manuel Villaverde Cabral, Karin Wall, Sofia Aboim and Filipe Carreira da Silva (orgs.), Itinerários. A Investigação nos 25 Anos do ICS. Lisbon, Imprensa de Ciências Sociais.

TAYLOR, Charles, 2007, A Secular Age. Cambridge, MA, Belknap Press.

Ter HAAR, Gerrie, 2003, "Who defines African identity? A concluding analysis", in James L.

Cox and Gerrie ter Haar (eds.), Uniquely African? African Christian Identity from Cultural and Historial Perspectives. Trenton, NJ, and Asmara, Ethiopia, Africa World Press.

—, 1998, Halfway to Paradise: African Christians in Europe. Cardiff, Cardiff University Press. Van DIJK, Rijk, 2004, "Negotiating marriage: Questions of morality and legitimacy in the Ghanaian pentecostal diaspora”, Journal of Religion in Africa, 34 (4), pp. 438-468. 